\title{
Gene-driving management practices in the dromedary husbandry systems under arid climatic conditions in Algeria
}

\author{
Derradji Harek ${ }^{1,2^{*}}$ (D, M'hamed El Mokhefi ${ }^{3}$, Hacene Ikhlef ${ }^{2}$, Rachid Bouhadad ${ }^{4}$, Hocine Sahel $^{1}$, \\ Noreddine Djellout ${ }^{5}$ and Fodil Arbouche ${ }^{6}$
}

\begin{abstract}
Changes in socio-economics, demography, politics, and climate in arid and semi-arid regions in recent decades have led to profound transformations in livestock practices, particularly in the management of local animal resources. The dromedary Camelus dromedarius has always played an important role in human life history in Algeria; it provides a substantial contribution in protein production such as milk and meat, and it is used as means of transportation by local populations. It is well-adapted to arid environments and has a satisfactory potential for food production that enables economic security to locals, especially in the context of climate change. This paper adds supplementary yet valuable information to the current knowledge on camel genetic diversity related to different management practices. Genetic and phenotypic variations and the underlying management practices are studied to understand differences between breeds, for a better resource management. The survey of 277 camel breeders across the Algerian desert revealed a genetic diversity in terms of breeds driven by four pastoral practices. According to coat colour and morphological aspect, the camel population "Tergui" corresponds to three breeds, namely Mahri with 53.13\% of the population, Marouki (43.22\%), and the single-ecotype Azerghaf (3.65\%). Mahri is a mixture of Amelal and Abahou ecotypes that are being outnumbered by Marouki's ecotypes (Atelagh and Alemlagh). This biodiversity is under real threat because of the behaviour of pastoral societies that pushes breeders to turn to breeds with a high market value. Several useful conservation methods, including the use of modern farming systems, could be positively used and/or improved, in order to protect the genetic variety and help breeders realize a good living out of rearing camels.
\end{abstract}

Keywords: Desert, Pastoralists, Transhumants, Genetic diversity

\section{Introduction}

In Saharan regions, the dromedary is a prestigious domesticated species well-adapted to desert climates and constraining conditions; it provides milk, meat, and hair products as well as services, while other animal species would suffer from heat and lack of feed and water. This adaptation is due to its great resistance to heat and long

\footnotetext{
* Correspondence: derradji11@gmail.com

'National Institute of Agronomic Research of Algeria (INRAA), 2 rue Ouadek BP 200, Hassen Badi, 16200 El Harrach, Algiers, Algeria

${ }^{2}$ National Superior School of Agronomy (ENSA), Avenue Hassan Badi, 16200

El Harrach, Algeria

Full list of author information is available at the end of the article
}

periods without drinking water combined with capacity to make better use of feed resources characterized by their low availability and limited nutritional value (Sawadogo et al. 1998). The dromedary Camelus dromedarius, like all other herbivores of arid and semi-arid areas, faces seasonal difficulties of feed and water scarcity both in quantity and quality (Moaeenuddin et al. 2004; Wernery 2006). It also faces several challenges that result in low production rates because of traditional camel husbandry systems (Kadim and Mahgoub 2013). For this reason, camels are considered as livestock species of secondary interest (FAOStat 2020). 
In Algeria, camel farming occupies an important place in both the local and national economy (Abiola and Laporte 1998). Locally, dromedary production is an important protein resource (Faye et al. 2014; Faye and Brey 2005). The camel is also of great importance in agricultural production systems of the arid and semi-arid areas (Kouadja et al. 2018); these systems are undergoing profound changes, both in terms of herd management and productive orientations. The interest of local people in animal production remains a major asset for food safety, animal genetic resource conservation, and social stability, especially for nomadic populations (Adamou 2008). This growing interest in animal raising and breeding and its subsequent economic importance have always been bound to the evolutionary history and human civilization since the Neolithic era. However, the different modes and practices of animal genetic camel husbandry remain very little documented (Harek and Bouhadad 2008). Upto-date, few studies are published on camel farming systems in North Africa, i.e. Algeria (Adamou 2008; Bedda et al. 2019; Ben et al. 2019; Longo-Hammouda et al. 2011), Tunisia (Salmi et al. 2018), and Morocco (Michel et al. 1997; Faye et al. 2014; Kamili et al. 2020). Other investigations within the last decade on camel husbandry were conducted in Saudi Arabia (Abdallah and Faye 2013) and Mauritania (Biya et al. 2021). However, the typologies revealed by these authors were built on unstandardized sets of variables (rate of mobility, reproduction, and feeding or care practices), which limits the comparisons between systems.

To our knowledge, no studies on camel production systems in Algeria are available, with the exception of the typological analyses designed by Harek and Bouhadad (2008) and a few reports in the grey literature limited to specific regions. The scarcity of data is likely due to the complexity of the field and the difficulty to reach the nomadic populations across the vast extent of the Sahara. The country is experiencing significant changes in pastoral and agro-pastoral systems due to climate change, economic globalization (milk marketing), and urbanization (Faye et al. 2014). Thus, a supplementary constraint adds up for breeders who are continuously on the move in quest of water and fodder along the everchanging Saharan landscape.

The present study was carried out with the aim of characterizing the diversity of camel farming practices and husbandry and their zootechnical performances, in order to establish a genetic improvement plan for the maintenance of local camel resources. The information resulting from the surveys on breeders would allow definition of the different types of farming systems practised by using statistical analyses and is therefore of major importance, combining the morphological characteristics of the animals and the management methods implemented by the breeders (Tichit et al. 2004). However, the use of appropriate methods to assess study parameters of camel livestock is constrained due to the difficulties of collecting crucial data in highly mobile and dispersed herds (Lesnoff et al. 2007). The implementation of individual animal monitoring may be a solution, but it is very expensive (Bebe et al. 2002). Moreover, it would be interesting to establish the relationships between farming types and intra-specific diversity. Another option would be to set up herd monitoring with simplified procedures (Madani et al. 2002), but this is complicated in a context of high mobility (nomadism and transhumance). In addition, we aimed to define the functioning of the husbandry modes and identify the underlying ecotypes of the "Tergui" population. Finally, we hoped to define the problems and obstacles that hinder its development in the region. Thus, we add a stepping-stone to the knowledge related to camels and a valuable piece of information for the actions to be taken by policy-makers and the different actors in the field. We note that camel husbandry systems are not unchangeable and current trends attest to the ability of herders to adapt their strategies to current global changes (Faye 2018).

\section{Material and methods \\ Geographical context}

The study was conducted in the region of Tamanrasset $2000 \mathrm{~km}$ to the south of the capital Algiers (Fig. 1). Algeria is located in North Africa with a human population more than 42 million. The Algerian camel population is estimated at 381,882 heads representing $1.18 \%$ of the world population, $1.40 \%$ of the African population, $4.25 \%$ of the Arab population, and $4.39 \%$ of the Maghreb population which puts Algeria at the 14th rank in the world and in the top 5 in the Arab world. At a local scale, camels have a prominent place in the area of Tamanrasset with more than 84,901 heads, of which more than 13,170 heads are present in the Hoggar (MADR 2018, FAOStat, 2018). However, the exact number of camel breeders is unknown due to the fact that they practise transhumance all year round.

\section{Data collection}

To conduct this study, a cross-sectional survey was carried out on 277 breeders. The farmers had mixed herds of goats, dromedaries and sheep. The questionnaires covered all aspects of animal husbandry. Both quantitative and qualitative information was collected. The questions focused on herd size, diversity, nature, and importance of the systems practised. Practices and functioning of camel farms were described based upon the periods of distribution of complementary feeds, the criteria for selection of breeding stock, reproduction and 


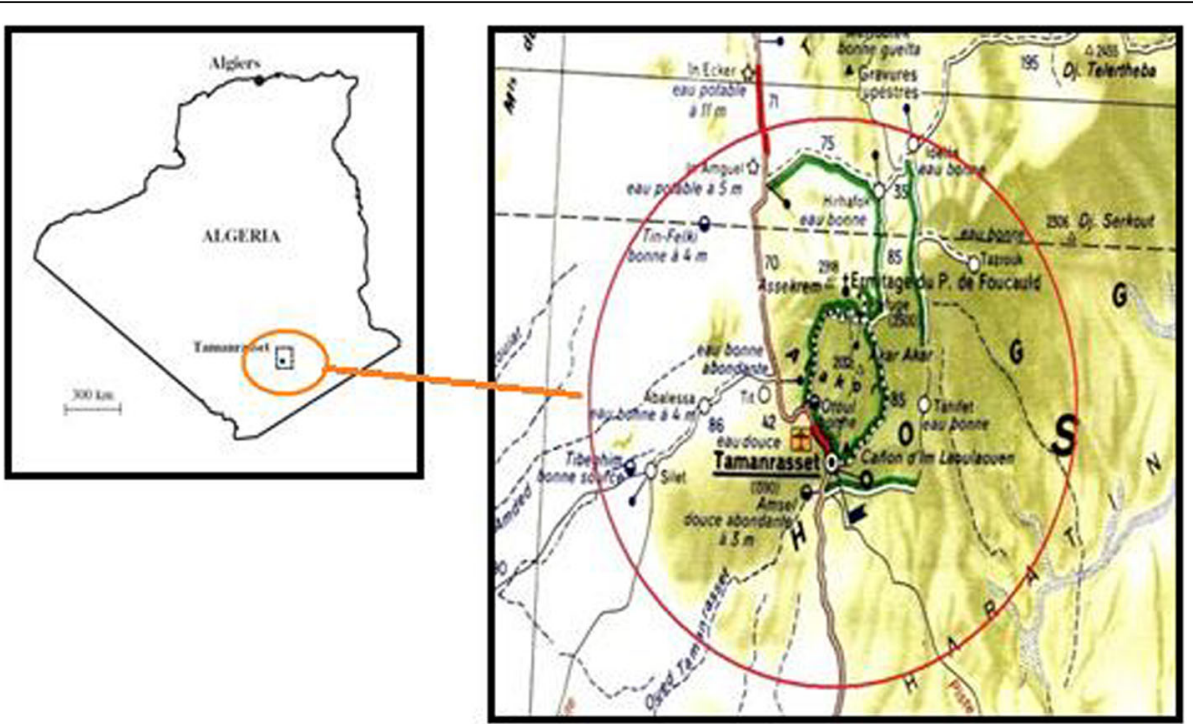

Fig. 1 Study area around the region of Tamanrasset under arid climate

weaning, and the type of products intended for sale. The baseline data used a set of codes for the quantitative and qualitative variables studied, considering that the qualitative variables were transformed into quantitative variables for the multivariate analysis. Breeders were randomly selected so as not to have any external influence that could be in favour of more dynamic test cases in terms of the breeding system. Only one condition was placed on the choice those surveyed: they were camel breeders, regardless of the number, the type of breeding practised, and the types of other animals that they would breed. The discriminating variables were chosen in such a way as to limit as much as possible the estimates made by the breeders, while keeping the guideline of the number, the type of breeding practised, and the "breeds", which were determining factors in this study (Fig. 2).

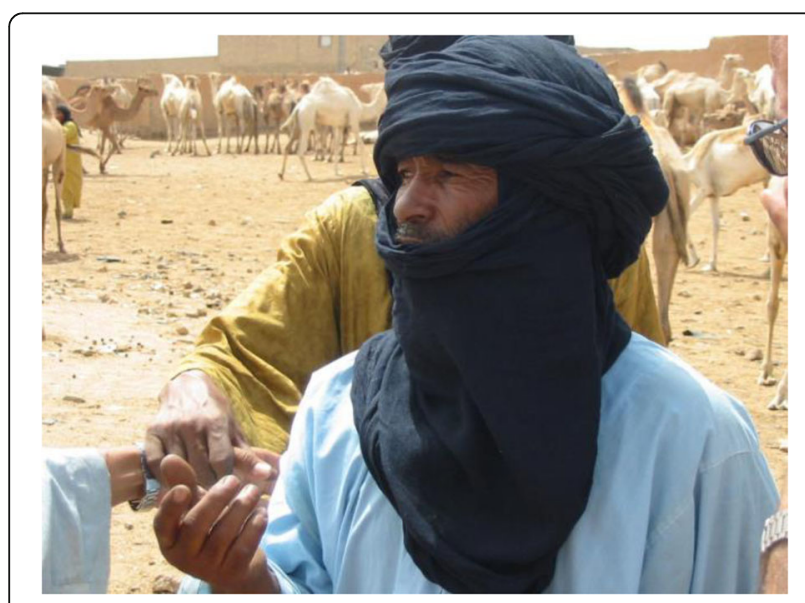

Fig. 2 Survey of camel breeders in the Tamanrasset region

\section{Data analysis}

The database has been entered on Excel and has been the subject of a multi-factorial analysis with Statistica 8.0 (StatSoft 2008), which represented a possible statistical strategy (Escofier and Pagès 2016; Pagès 2002). The segregation criteria chosen are as follows: qualitative and quantitative variables, which reveal the relationships existing within the different types and systems of practising camel farming, the perception of the breeders for improvement of the practised modes, and the management of this resource. Collected data was used in the PCA and the HAC of multi-variate analysis. The objective is to present in graphic form the maximum amount of information contained in a data table made up of individuals and quantitative variables (Philippeau 1986).

\section{Results and discussion}

In this section, we discuss the 6 major management indicators related to camel breeding.

\section{Workforce, livestock structure, and evolution}

The 277 breeders surveyed raised livestock estimated at 27,516 heads distributed as follows: $38 \%(n=10,457)$ goats, $36 \%(n=9823)$ camels, and $26 \%(n=7236)$ sheep. The sizes of the 277 farms showed that $60.7 \%$ of the livestock was owned by $27 \%$ of the breeders, $12.8 \%$ owned by $18.2 \%, 11.80 \%$ by $11.7 \%$, and $11 \%$ owned by $24.7 \%$ of the breeders. A low rate of only $3.70 \%$ of the livestock was owned by $18.4 \%$ of the herders (Table 1 ). These figures, however, only give an approximate indication of the ownership structure. Indeed, the declarations of the breeders often hide the reality of the numbers, which makes it difficult to make a real assessment. 
Table 1 Distribution of farm classes by breeder and by head including goats, dromedaries, and sheep

\begin{tabular}{|c|c|c|c|c|c|c|}
\hline & \multicolumn{5}{|c|}{ Classes of farms expressed in number of heads } & \multirow[t]{2}{*}{ Total } \\
\hline & $<21$ & $21-40$ & $41-60$ & $61-80$ & $>80$ & \\
\hline Number of breeders & 51 & 69 & 50 & 32 & 75 & 277 \\
\hline Percentage (\%) & 18.4 & 24.7 & 18.2 & 11.7 & 27 & 100 \\
\hline Number of heads & 1027 & 3012 & 3542 & 3235 & 16,700 & 27,516 \\
\hline Percentage (\%) & 3.7 & 11 & 12.8 & 11.8 & 60.7 & 100 \\
\hline
\end{tabular}

The number of camels, goats, and sheep has increased during the period from 2003 to 2014 (Fig. 3). This situation has resulted in the decrease in forage resources due to overgrazing, which did not prevent an unequal evolution in the number of the different types of livestock:

- The relatively lower increase in the camel population (1296 heads/year between 2003 and 2014) is due to the particularity of its diet compared to other species. It feeds on plant species especially and preferably, Atriplex halimus, that disappears during the dry season. In periods of drought, breeders are forced to sell the least resistant individuals and control the reproduction of females.

- The relatively higher increase in goat numbers, in low proportions (3047 heads/year between 2003 and 2014), is explained, on the one hand, by the need for self-consumption since they provide the dairy products that constitute one of the basic elements of households and, on the other hand, by the capacity to adapt to the natural conditions of the environment.

\section{Husbandry modes}

Four modes of animal husbandry were identified in the region, namely nomadic, transhumant, semi-nomadic, and sedentary representing $41 \%(n=4.027), 21 \%(n=$
2.063), $18 \%(n=1.768)$, and $20 \%(n=1.965)$, respectively (Table 2).

The size of the camel herd does not follow any specific pattern related to the breeder's financial or social conditions. The structure of the camel herd is composed mainly of females which the breeder tries to manage according to objectives such as:

- Animals for selection or replacement of the herd

- Animals intended for reproduction

- Animals for sale

- Animals for slaughter

This situation is driven by the breeder's household needs according to which he can sell about 10 camel heads per year if the needs are important or just 1 to 5 to cover basic needs. As for renewal, it is generally based on the herd itself and the phenotypic criteria that prevail in this case, since the breeder generally considers the size and conformation of the animals. Helped by the hardiness of the animals and their adaptability, breeders have always ensured a balance of the herd and a maintenance of its already established performance. Breeders are convinced that the best way to protect their animals is to know how to manage them by controlling reproduction, especially when herds of different owners are mixed for long periods, which is common in the region.

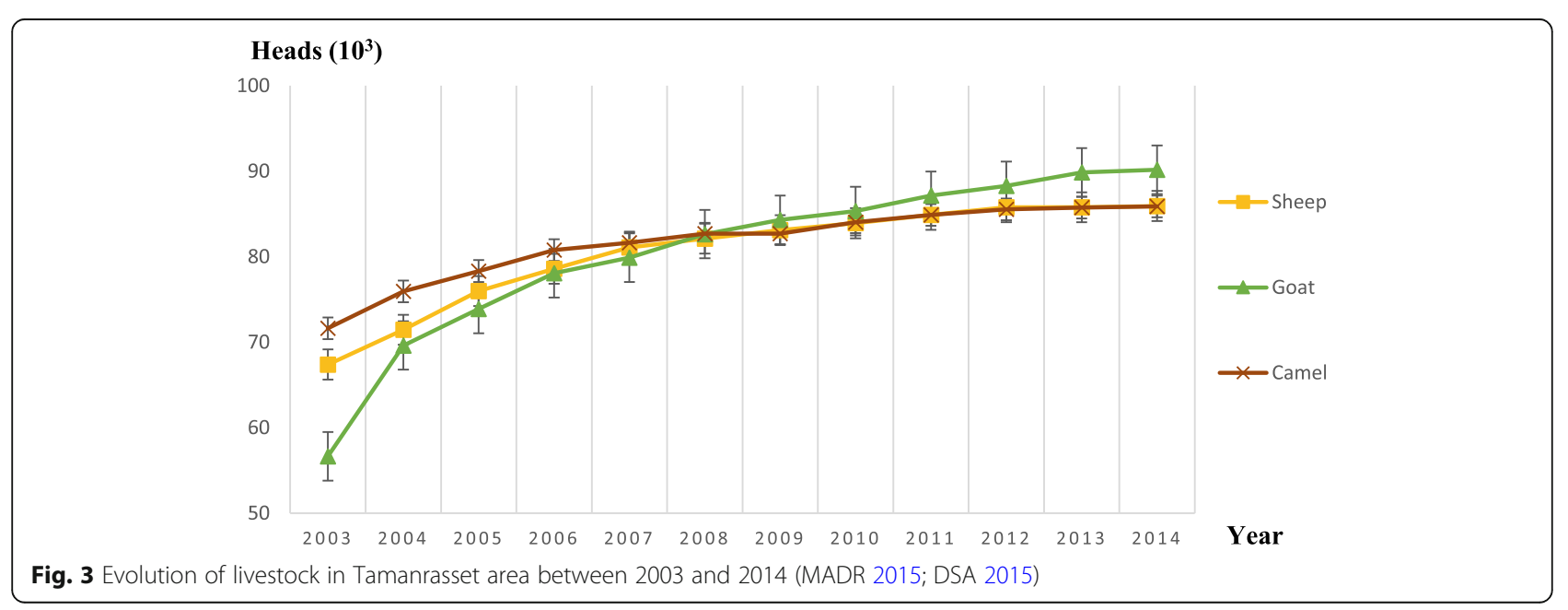


Table 2 Distribution of breeders according to the size of their camel herd and husbandry mode

\begin{tabular}{|c|c|c|c|c|c|}
\hline \multirow{2}{*}{$\begin{array}{l}\text { Camel } \\
\text { herd size } \\
\text { (number } \\
\text { of } \\
\text { heads) }\end{array}$} & \multicolumn{4}{|c|}{ Husbandry mode } & \multirow[t]{2}{*}{ Total } \\
\hline & Nomadic & Transhumant & Semi-nomadic & Sedentary & \\
\hline$<20$ & 325 & 250 & 200 & 125 & 900 \\
\hline $21-40$ & 754 & 650 & 153 & 330 & 1887 \\
\hline $41-60$ & 480 & 540 & 240 & 280 & 1540 \\
\hline $61-80$ & 497 & 500 & 660 & 230 & 1887 \\
\hline$>80$ & 1971 & 123 & 515 & 1000 & 3609 \\
\hline Total & 4027 & 2063 & 1768 & 1965 & 9823 \\
\hline
\end{tabular}

\section{Livestock feed}

The camels and goats feed on the vegetation of the place where they graze with a preference for any vegetation of leguminous or grassy type that grows especially in rainy years and is more abundant in certain seasons, both on the regs which is a stony desert essentially made up of rocky formations, and at the edges of the wadi (river) beds of the Hoggar massifs. According to Moskal (1983), Saharan fodder constitutes more than half of the diet of ruminants. Unlike other ruminants, the dromedary's exceptional walking ability and eclecticism allow it to compose its diet with very scattered and often very thorny plants found in arid areas (De Fabrègues 1989). It feeds upon woody and coarse plants. In addition, and taking into account their specificities, the pasture sites are diverse according to the composition of their floristic procession, their location, and the palatability of the available plants. The pastures can be classified into two categories:

- "Acheb" or ephemeral pasture that is made up of herbaceous and annual vegetation

- Pastures of perennial and woody and bushy vegetation or halophytic vegetation. The woody perennial vegetation such as Aristida pungens is intended for the maintenance of the animal (Fig. 4).

In the area of study, we did not observe a great diversity in food resources; $85 \%$ of livestock feed resources come from rangeland. The rest is provided in the form of relatively varied barley-based complementation in camel feed. A ration of more or less energy is allowed at certain physiological stages of the animal, but this is not possible throughout the year for the whole herd because of limited barleyavailability. In order to determine the composition of the vegetation with sufficient precision, an exhaustive inventory of the foraging potential of the region for animals was established by Harek and Bouhadad (2008). In general, the patterns have remained intact with a dense and diversified vegetation cover; we can mention for example the plants most grazed by the camel with a variable degree of palatability in the Hoggar region: Tamarix aphylla, Tamarix gallica, and other vegetative associations composed by plants such as Panicum turgidum, Balantite aegyptiaca and Cornulaca monocantha, Schowia purpurea, and Aristida pengens. According to Harek and Bouhadad (2008), in Hoggar region, the plants most grazed by the dromedary are Astragalus vogelii, Morettia canescen, Tribulus alatus, Panicum turgidum, Acacia radiana, Acacia seyal, Schowia purpurea, Cornulaca monocantha, Aristida pungens, Moricandia arvensis, Schouwia purpurea, Tribulus terrester, Trichodesma calcaratum, Forsskaolea tenacissima, Maerua crassifolia, Salvodora persica, Atractylis aristata, Balanites aegyptiaca, Echinops bovei, Colocynthis vulgaris, and Atriplex halimus. In Hoggar, it is recommended that a more in-depth study be proposed on the extent to which fodder grazed by dromedaries covers the needs of the animals in a strategic manner so that performance is not hampered by nutrition.

\section{Selection of genitors}

Closely related to feeding, reproduction is also the indicator parameter of good or bad management of the breeding. It is an indicator that provides information on the herd's degree of performance and its level of productivity. Results of the present study showed that breeders choose reproducers according to ancestry and conformation, and these criteria are met in $78 \%$ for the males and $43 \%$ for the females. Other criteria are considered as follows: (a) for female camels: corpulence and zootechnical performance $(6.8 \%)$, early entry into heat and corpulence (6\%), zootechnical performance (5\%), zootechnical performance and early entry into heat (2.5\%), early entry into heat (1.4\%), and zootechnical performance, corpulence, and early entry into heat (3\%), and (b) for male camels: zootechnical performance (23\%), body build and zootechnical performance (16.8\%), early entry into heat and body build (12.5\%), early entry into heat and zootechnical performance and body build (2\%), and early entry into heat $(0.7 \%)$. In conclusion, it can be said that the breeder chooses his breeding animals solely based on phenotypic criteria. 

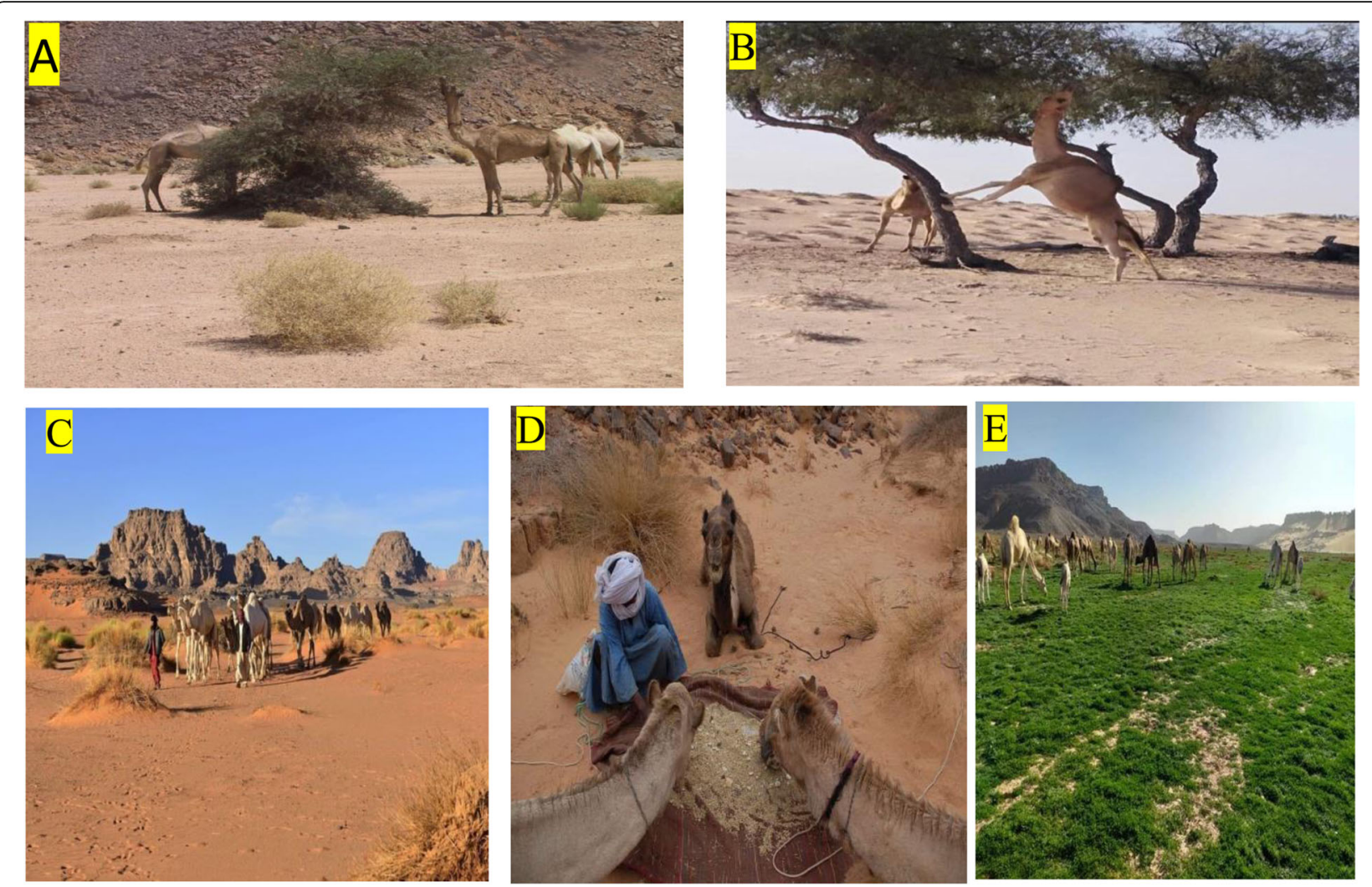

Fig. 4 Camel livestock feed in the Tamanrasset region. A, B Grazing in Acacia radiana trees; C grazing in dry periods; D food complementation in barley; $\mathbf{E}$ thrust of grazing after rain

\section{Reproduction}

Reproductive performance criteria, namely age at first calving, length of lactation, and calving interval, are crucial for milk production. They are relatively homogeneous in the major camel producing countries. They indicate the willingness of breeders to maximize the physiological possibilities of dairy camels: one camel calf per 2 years and 12 months of lactation. The finding in this study is that the calving rate varies greatly, especially according to the level of feed provided by pastures. It varies from an average of $100 \%$ in transhumant herds to $58.43 \%$ in sedentary and semi-nomadic herds $37.5 \%$. The age of the first mating varies between 30 and 36 months, with an average of 32 months, which is fairly consistent with the literature. The first mating can be early, if the animal is subjected to an energetic and abundant diet. The male, on the other hand, is not taken to reproduction until reaching 7 years of age, although sexual maturity is achieved between 3 and 4 years of age. This practice is justified by the fact that the male is only introduced into the female herd when he is able to protect himself from other adults. These results do not correspond with Elwishy (1987) neither with Elwish (1988) who considered that the dromedary was dominated by behaviours, whose heats are often shorter, more frustrating, and later: 27 months minimum against 9 to 12 months for early dairy breeds. This 27 -month period between heats means that camels will only give birth once every 2 years, which would correspond to a herd calving rate of about $50 \%$. This is proof that improving the feeding reduces the interval between calvings. The distribution of parturition throughout the year is also a very important factor in both extensive systems and dairy production because it ensures sustained production (Faye 2004).

\section{Genetic variability of the population}

The Algerian species is characterized by various variants considering the phenotype. They are generally breeds strongly crossed with the Arab dromedary. But beyond the genetic data, which remains scarce (Longo-Hammouda et al. 2011; Harek and Bouhadad 2008; Benlamnaouar 2000), the main common point remains a strong decline in numbers and a noticeable decline of some sub-types like Naili and Ouled Sidi Cheikh. The national camel population belongs to two major genetic groups: Châambi and Tergui. It has eight inventoried sub-types: the Reguibi, the Sahraoui, the Aftouh camel, the Ajjer, the Ait Kebbach, the Ouled Sidi Cheikh, and the steppe camel. This distribution was confirmed by studies 
carried out in Algeria by several authors (Boué 1952; Lasnami 1986; Ben Aissa 1988; Oulad Belkhir 2013, Harek et al. 2017). Two populations were reported: Tergui and Sahraoui populations are the most preferred saddle animals (Harek and Bouhadad 2008) often sought after in the Sahara as a genitor (Ouled Laid 2008). The frequency of the "Tergui" population encountered was 301 individuals; the phenotypic types are highly variable and diversified. However, we noticed the importance of the Amelal ecotype $(37.87 \%)$ in the whole population studied. The Spotted Magpie ecotype, or Azerghaf, was poorly represented $(3.65 \%)$, and it was found in the localities of Izernene, Tarahnent, Izerzi, In-Amguel, Hirafok, and Tamanrasset. The Alemlagh ecotype was found in all surveyed localities with a relatively higher frequency of $22.26 \%$ compared to the Amelal ecotype (Fig. 5).

\section{Multivariate analysis}

The multivariate analysis allows the maximum amount of information to be extracted in a simple and coherent form from a very large dataset and to highlight the inter-relationships between variables and the similarities and contrasts between the populations analysed by testing the inter- and intra-relationships of the variables studied. A PCA and a HAC were realized on all 277 farms, highlighting the diversity of the farms, which shows the percentage of the total variance explained by each factor. It can be seen that the first 04 axes contain more than $59 \%$ of the information; this means that the presentation on the first 04 axes will have more than $60 \%$ of the variability preserved (Table S1). The results show that the two first axes do not represent a good description of the dispersion of individuals since they only explain almost half of the total variation $41 \%$. So there is no clear separation of the axes. Cumulation reaches $100 \%$ up to a factor of 15 which explains the importance of the contribution of each variable. The assessment of the contribution of each variable based on the correlations makes it possible to prioritize the variables responsible for the formation of each axis. The variables that contribute more to the distribution of individuals on axes 3 and 4 where the camel is dominant along with the species that make up the population are variables that explain the distribution of individuals along axis 5 . We note that the variables that contribute most to the distribution of individuals on axes 3 and 4 where the dromedary is dominant as well as the branches that make up the population (Mahri and Marouki) are variables that explain the distribution of individuals on axis 5. On the other hand, axis 5 contributes to the explanation of the variable Azerghaf. In contrast, axes 4 and 5 contribute to the explanation of the variables goat and cattle (Table 3).

The graphical representation of the variables on axis 1.2 confirms these contributions cumulating 40.59\% inertia. These projections are relatively far from the centre, which explains the absolute contribution of each variable to the explanation of axes 1-2. This
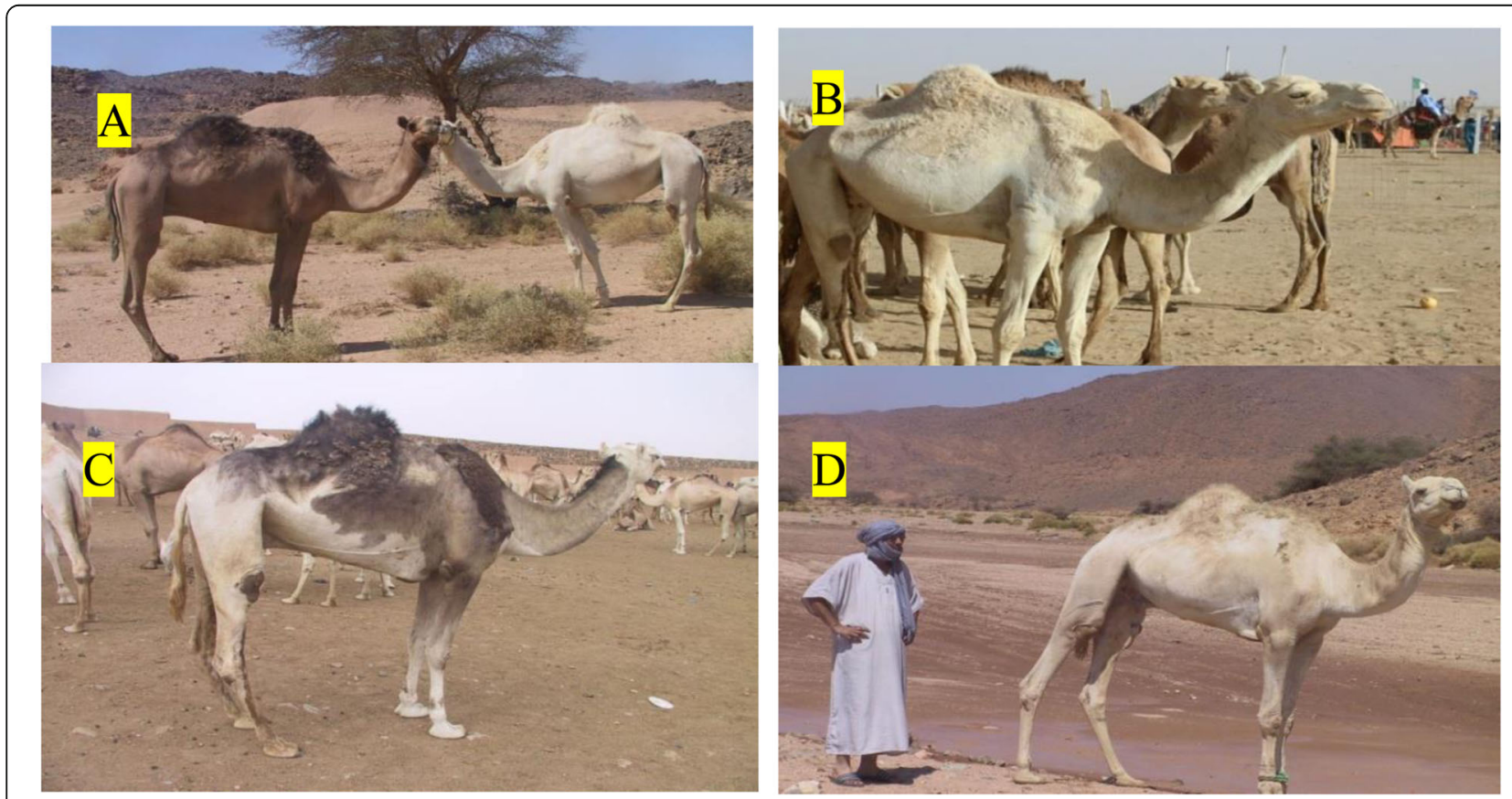

Fig. 5 Diversity and ecotypes of the "Tergui" population in the Tamanrasset region. A Atelagh ecotype; B Amelal ecotype; C Azerghaf ecotype; D Abahou ecotype 
Table 3 Contribution of variables (squared cosine)

\begin{tabular}{llllll}
\hline & F 1 & F 2 & F 3 & F 4 & F 5 \\
\hline Sedentary & 0.165 & 0.111 & 0.027 & 0.000 & 0.005 \\
Nomadic & 0.003 & 0.155 & 0.238 & 0.211 & 0.014 \\
Semi-nomadic & 0.021 & 0.269 & 0.240 & 0.013 & 0.021 \\
Transhumant & 0.148 & 0.063 & 0.049 & 0.060 & 0.009 \\
Sheep & 0.008 & 0.031 & 0.126 & 0.286 & 0.036 \\
Cattle & 0.000 & 0.116 & 0.068 & 0.210 & 0.003 \\
Goat & 0.003 & 0.047 & 0.024 & 0.101 & 0.110 \\
Camels & 0.004 & 0.009 & 0.041 & 0.043 & 0.019 \\
Mahri & 0.001 & 0.000 & 0.086 & 0.002 & 0.116 \\
Marouki & 0.003 & 0.026 & 0.000 & 0.012 & 0.271 \\
Azerghaf & 0.001 & 0.033 & 0.003 & 0.021 & 0.385 \\
\hline
\end{tabular}

gives us information on the typology of camel farms and the structuring of the "Tergui" population; the dominance of the transhumant farming mode is linked to camel farms and to a lesser extent goat farming, while the sedentary farming mode is linked to sheep farming. On the other hand, for the breeds that make up the population, Mahri $(0.99 \pm 0.10)$ and Azerghaf $(0.25 \pm 0.44)$ dominate the population with an intermediate position for Marouki (0.88 \pm 0.32$)$. These results of analysis represented graphically constitute good projection plans despite the fact that the explanation by the first 03 axes is not relatively strong 53.86\% (Fig. 6).

However, the projection of the individuals on plane 12 shows the formation of 04 main groups (Fig. 7). On the one hand, axis 1 opposes the individuals in relation to their breeding methods. The individuals are grouped on the negative section of the $x$-axis and correspond, for the most part, to individuals of transhumant and seminomadic farming modes for camel farming. On the other hand, axis 2 opposes sedentary and nomadic individuals linked to goat rearing.

According to this description, it can be said that the semi-nomadic farming mode occupies an intermediate position with a tendency towards the sedentary farming mode. The results of the typology allowed distinguishing, according to the variables of performance and production strategies, four types of operations involved in the production and breeding of dromedary in the study area. This great diversity observed in the production system seems however new in the south of Algeria. Camel production systems have undergone a very high degree of profound changes, both in terms of herd management and productive orientation. This corroborates the conclusions of Ben Bouguerra (1991) and Bensahraoui and Kerrache (1999); and that livestock farming remains traditional and evolves on the margins of technical

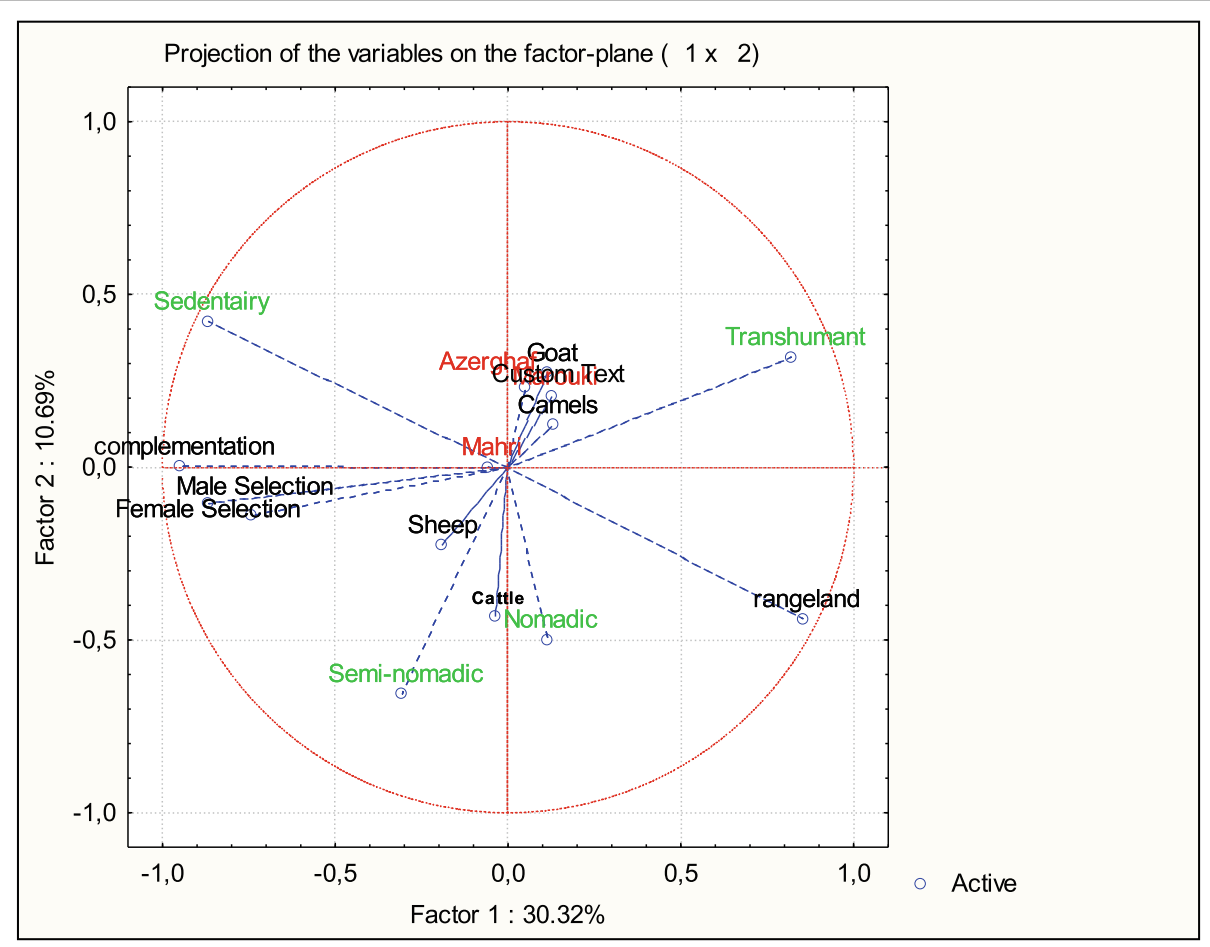

Fig. 6 Circle of correlation of quantitative variables on the axes 1-2 


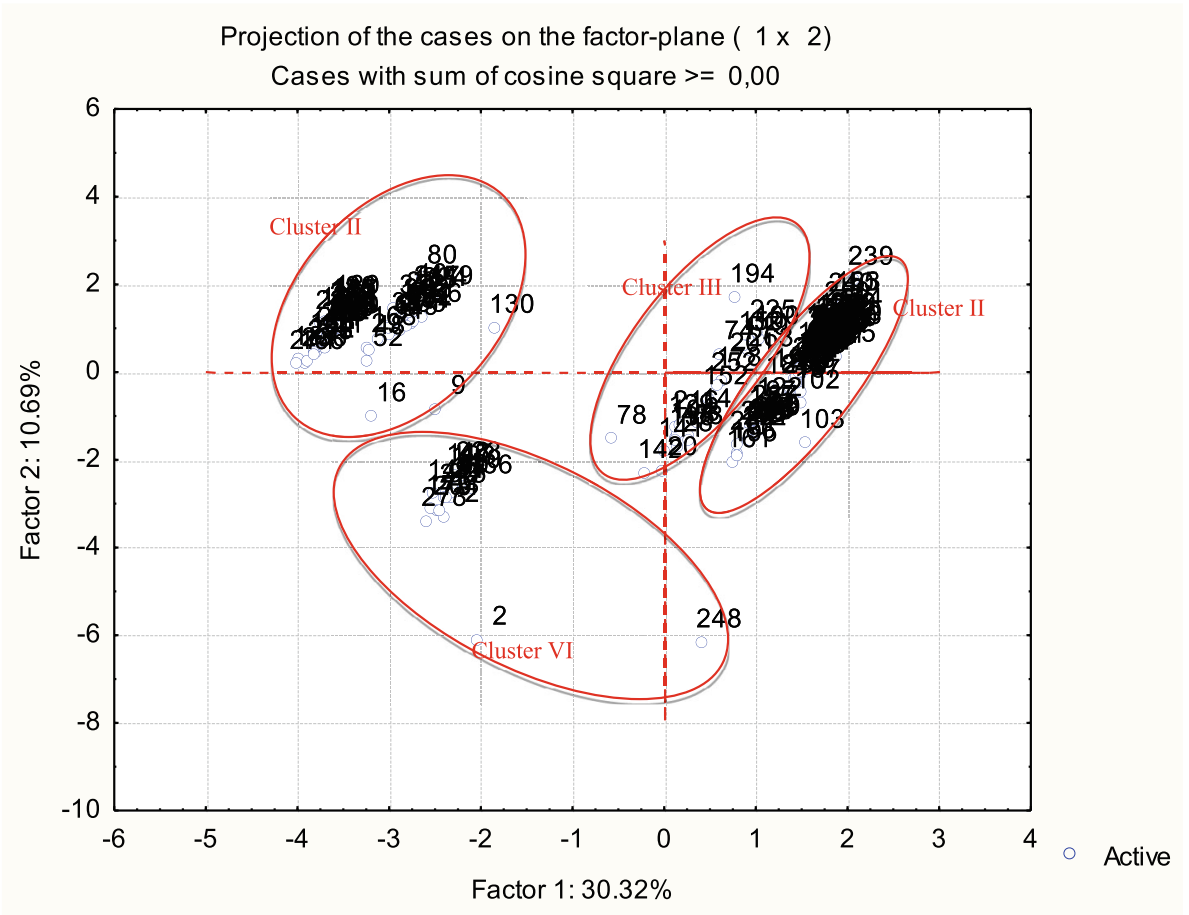

Fig. 7 Diagram of ordination derived from the PCA in terms of projection axes 1-2

progress and that it is exploited mainly for household needs.

- The first group (cluster I)

The transhumants are in periodic movements organized by the availability of water and grass with $20 \%$; their logic is the search for pastures and watering sources for the livestock. The herders make regular or even daily trips away from the camps. Nomads travel the longest distances $(41-50 \mathrm{~km} /$ day) for $76 \%$ of them. For all the herders surveyed, the average distances traveled are $50 \mathrm{~km}$ for $50 \%$ of the cases and 31 to $40 \mathrm{~km}$ for the other cases. The breeds that make up this centre are Azerghaf and Marouki, and this is explained that during travel these breeds are chosen for their resistance and production, especially milk. Significant variations have been observed. They can be determined by the following factors: nature, size of the herd, and the season. It often happens that stray animals are only found after a long search or returned to their owners by other smugglers who have collected them. These situations are not a cause for concern for the breeders who can count on the inter-tribal solidarity that is very active in these regions.

- The second group (cluster II)

Nomads who live in the desert and use tents as a means of housing account for $41 \%$. It should be noted that for their strategy of life the nomadic breeders have the largest herds; $36 \%$ have more than 30 goat heads, and $49 \%$ have more than 30 camel heads of the Mahri breed known for its abilities and interest among the Touaregs of the region. Owning a large herd is synonymous with a source of survival as breeding is their only source of income. In this regard, it is specified that nomadism as a way of life was born from economic imperatives related to the geo-climatic conditions of Hoggar. The topography and weather leading to the scarcity of rainfall and the dry soil have led the herders to long transhumance in search of water and grass.

- The third group (cluster III)

These breeders use a mixed housing mode (18\%), using tents at certain times of the year, when vegetation is abundant and this allows the herds to graze for several days. When the vegetation dries out in the sun and water points are scarce, there is no justification for a continuous presence of livestock on the rangelands. The sedentary people and, to a lesser degree, the seminomadic people, develop survival strategies based on the multiplicity of income resources (livestock, agriculture, and trade). However, the agricultural activity practised by sedentary people has seen its importance diminish in recent years due to sociological and hydrological factors. The survey shows that $11 \%$ of herders have tourism as a secondary activity. The analysis of their livestock assets 
also reveals a differentiation according to the age of the stockbreeders. In fact, there is a predominance of camel herds of more than 80 heads among breeders over 50 years of age and a higher proportion of herds of between 2 to 40 heads among those under 50 years of age, who have recently entered the profession and therefore have only a modest herd size. Paradoxically, however, these age-induced differences tend to diminish with respect to goat herd ownership. Large goat herds are found in all age classes $(41.8 \%$ among breeders aged $30-50$ years; $36.5 \%$ among breeders aged 51-70 years). This phenomenon is explained by the privileged position of goats and the profitable breed, especially Terguia in the region. It provides milk, from which is made the "Ourdi" (very popular butter) and meat and hair for making tents. The possession of goats has an additional advantage over camels, that of better resisting the decrease in pasture during years of severe drought since they consume small quantities.

The sedentary breeders represent $21 \%$, and they generally have a lower breeding activity and own a few heads of livestock, especially sheep. They have a short-term vision of problems, favouring rapid solutions to actions that generate development of this species.

The dendrogram structure of the hierarchical ascending classification (HAC) confirms the groupings obtained by the PCA (Fig. 8).
However, this great diversity of production systems seems to be new, due to the appearance of other more sustainable practices and production systems. This can be explained by the herders' perception of their activity which appears to be clearly determined by their economic position. Only the "most affluent" have this ability to think of their knowledge as the result of a practice and means of action on the factors of production. Among the most deprived, this constant reference to the "family heritage" and to the founding myths tends to justify the continuity of their way of life. The current livestock systems could be more functional by identifying development opportunities and significant changes in the organization of mobility in time and space scales with the recent socio-ecological and political changes which could be an opportunity for camel development (Amsidder et al. 2021).

\section{Conclusion}

The work was carried out in the Hoggar region for the identification of breeding and husbandry systems and the structuring of the camel population "Tergui". We were able to provide a detailed description of the breeding situation and the underlying problems. Four livestock systems were identified: nomadic, transhumant, sedentary, and semi-nomadic. It can be concluded that the search for immediate solutions by breeders is

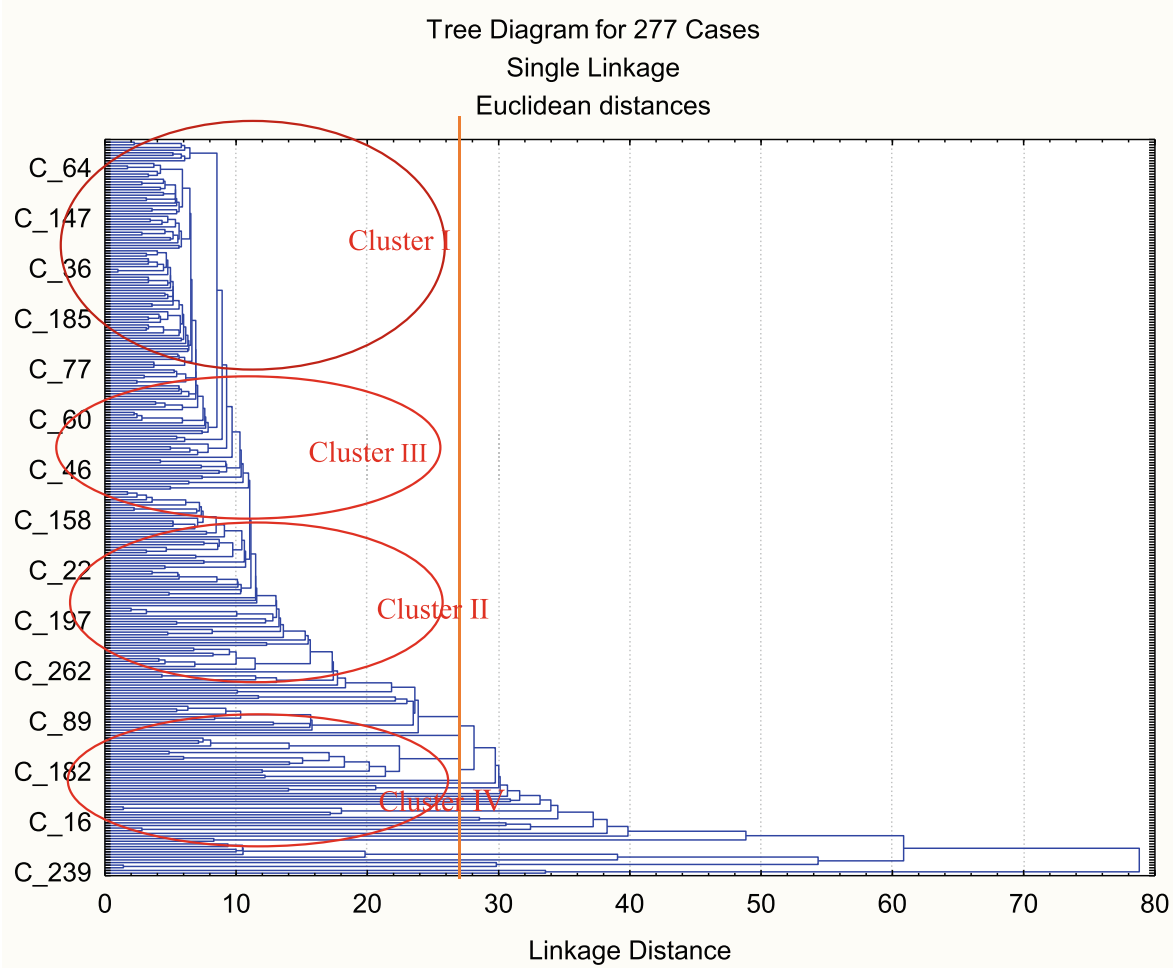

Fig. 8 Dendrogram from the hierarchical ascending classification $(\mathrm{HAC})$ of qualitative variables 
dictated not only by pressing needs, but also by a mistrust of state structures. This study highlights new modes and practices of camel farming systems trying to cope with the rapid growth in demand and interest in this species, despite the general context dominated by extensive systems with low production. The changes detected in evolution of animal management patterns would be influenced by the emergence of a new system offering a reliable outlet for breeders who aim at increasing productivity, especially milk production.

The work was able to provide more information and details on the Algerian camel population's genetic diversity in its natural environment. The most essential element for the future of this species relies on a good knowledge and control of its breeding. The population is structured into 3 breeds: Mahri, Marouki, and Azerghaf with very distinct ecotypes. Observations made in the region of Tamanrasset showed that the Amelal and Abahou ecotypes are threatened by absorption by the Atlagh and Alemlagh ecotypes due to the orientation of breeders towards more profitable value chains. Indeed, change in pastoral societies is pushing herders to turn to breeds with high market value for milk and meat. We are witnessing the gradual decline of breeds, i.e. Mahri and Azerghaf, with marked and unique zootechnical characteristics. This observation deserves to be taken into account within the framework of safeguarding camel's biodiversity. This would not be possible unless breeders are supported and fully integrated in the process of change, in which they should be the main actors. Further studies are urgently needed to assess the social, economic, and environmental consequences of establishing the semi-nomadic production system. It seems to be an appropriate alternative to supply the local population's increasing demand for camel milk, thus increasing the monetary value of camel farming.

\section{Supplementary Information}

The online version contains supplementary material available at https://doi. org/10.1186/s13570-021-00219-z.

Additional file 1: Table S1. Eigenvalues and the variability between different variables.

\section{Acknowledgements \\ This work was carried out within the framework of the surveys conducted in Algeria for the development of camel breeding, which was supported by the National Institute of Agronomic Research of Algeria (INRAA). We acknowledge the help of many colleagues from other institutions and universities. The authors are also grateful to the Direction des Services Agricole and the Chamber of Agriculture of the wilaya of Tamanrasset who facilitated the logistics for the realization of the surveys, as well as to the camel breeders of the region who gave their time for the collection of data.}

\section{Authors' contributions}

The authors contributed to the conception, design, data collection, and analysis and drafted the manuscript. Furthermore, the authors contributed to the questionnaire design, conducted the pilot, participated in data collection, provided information about the study area, and proofread the manuscript. All authors read and approved the final manuscript.

Funding

The authors did not receive any funding for this publication.

\section{Availability of data and materials}

The datasets used and/or analysed during the current study are available from the corresponding author upon request.

\section{Declarations}

Ethics approval and consent to participate

The data used are from a previous study of the PNR 1_CRA02_1994 project, which investigated camel breeding in the Tamanrasset region. The aim and purpose of the research were explained to community members during meetings. All participants were informed that they explain how the management of this resource is done.

\section{Consent for publication}

Not applicable.

The authors declare that the manuscript does not contain any personally identifiable information and all personal data is anonymous.

\section{Competing interests}

The authors declare that they have no competing interests.

\section{Author details}

${ }^{1}$ National Institute of Agronomic Research of Algeria (INRAA), 2 rue Ouadek BP 200, Hassen Badi, 16200 El Harrach, Algiers, Algeria. ${ }^{2}$ National Superior School of Agronomy (ENSA), Avenue Hassan Badi, 16200 El Harrach, Algeria. ${ }^{3}$ National High Veterinary School, Rabie Bouchama, Rue Issad Abbes, 16300 Oued Smar, Algiers, Algeria. ${ }^{4}$ University of Sciences and Technologies Houari Boumediene (USTHB), 16500 Bab Ezzouar, Algiers, Algeria. ${ }^{5}$ Veterinary inspection of the Tamanrasset Region, Tamanrasset, Algeria. ${ }^{6}$ University of Ghardaia, Scientific Zone, P.O. Box 455, Bounoura, Ghadaia, Algeria.

Received: 1 September 2021 Accepted: 13 October 2021

Published online: 17 February 2022

\section{References}

Abdallah, H.R., and B. Faye. 2013. Typology of camel farming system in Saudi Arabia. Emirates Journal of Food and Agriculture 25 (4): 250-260.

Abiola, F.A., and J.P. Laporte. 1998. Etude Socio-Économique Du Dromadaire Au Mali, En Mauritanie, Au Niger Et Au Tchad. Plan D'action En Faveur De L'élevage Du Dromadaire, 39. Dakar: Eismv.

Adamou, Abdelkader. 2008. L'élevage camelin en Algérie: Quel type pour quel avenir? Science et changements planétaires/Sécheresse 19 (4): 253-260.

Amsidder, L., V. Alary, and M.T. Sraïri. 2021. An empirical approach of past and present mobility management in the desert societies of camel breeders in South Eastern Morocco. Journal of Arid Environments 189: 104501. https://doi. org/10.1016/j.jaridenv.2021.104501.

Bebe, B.O., H.M.J. Udo, and W. Thorpe. 2002. Development of smallholder dairy systems in the Kenya highlands. Outlook on Agriculture 31: 113-120. https:// doi.org/10.5367/000000002101293958.

Bedda, H., A. Adamou, B. Bouammar, and B. Babelhadj. 2019. Le déclin des systèmes de production camelins dans le sahara septentrional algérien-cas de la cuvette de Ouargla, le M'zab et le Ziban. Livestock Research for Rural Development 31: 3.

Ben Aissa, R. 1988. Le dromadaire en Algérie. In : Tisserand J.-L. (ed.). Séminaire sur la digestion, lanutrition et l'alimentation du dromadaire. Zaragoza : CIHEAM, 1989. p. 19-28 (Options Méditerranéennes: Série A. Séminaires Méditerranéens; n. 2).

Ben Bouguerra, M. 1991. Caractérisation Des Systèmes D'élevages Du Dromadaire En Algérie - Cas Des Régions: Ouargla, Adrar, Tamanrasset. El-Harrach: Institut National d'Agronomie (INA).

Ben, Semaoune Youcef, Abdelhakim Senoussi, and Bernard Faye. 2019. El-Harrach El-Harrach. Livestock Research for Rural Development 31 (2): 19.

Benlamnaouar, N. 2000. Contribution À La Connaissance De La Population Cameline «Tergui» Dans La Wilaya De Tamanrasset: Cas De L'Attakor. Blida: Institut National d'Enseignement Supérieur (INES). 
Bensahraoui, T., Kerrache, A. 1999. Les Systèmes D'élevages Camelin Dans Le Hoggar. In: Thèse d'ingénieur d'état en agronomie saharienne Institut National de la Formation en Agronomie Saharienne (INFS/AS) Ouargla, 1999

Biya, M.B., Chrif Ahmed, C.Y. Dieye, A.K.M. Diop, R.B. Mohamed, A. Salem, M. Sidatt, et al. 2021. Typologie descriptive des systemes d'elevage camelin en Mauritanie. Livestock Research for Rural Development 33 (3): 18.

Boué, A. 1952. L'originalité Du Chameau. Revue d'élevage et de médecine vétérinaire des pays tropicaux 5 (3): 109-114.

De Fabrègues, Bernard Peyre. 1989. Le dromadaire dans son milieu naturel. Revue d'élevage et de médecine vétérinaire des pays tropicaux 42 (1): 127-132.

Direction des Services Agricoles (DSA). 2015 Statistiques Agricoles. Direction Des Services Agricoles De La Wilaya De Tamanrasset.

Elwishy, A.B. 1987. Reproduction in the female dromedary (Camelus dromedarius): A review. Animal Reproduction Science 15 (3-4): 273-297.

Elwishy, A.B. 1988. Reproduction in the male dromedary (Camelus dromedarius): A review. Animal Reproduction Science 17 (3-4): 217-241.

Escofier, B., and Pagès, J. 2016. Analyses Factorielles Simples Et Multiples-5e Éd.: Cours Et Études De Cas. Dunod. Paris France. https://www.dunod.com/sites/ default/files/atoms/files/9782100741441/Feuilletage.pdf.

FAOStat. 2018. Statistical Data. Rome: Food and Agriculture Organization of the United Nations.

FAOStat. 2020. Données sur les productions mondiales de lait et deviande pour les différentes espèces d'élevage. Rome: FAO www.fao.org/faostat/fr/\#data.

Faye, B. 2004. Performances Et Productivité Laitière De La Chamelle: Les Données De La Littérature. In Lait de chamelle pour l'Afrique; Atelier sur la filière laitière cameline en Afrique, Rome. FAO. pp 7-16.

Faye, B. 2018. What future for camel pastoralism in the world? In Proc. The 5th Conference ISOCARD Recent Advances in Camelids Biology, Health and Production, 12-15 Nov. 2018, ed. A. Sghiri and F. Kichou, 32-38. Laâyoune: IAV Hassan II.

Faye, B., and F. Brey. 2005. Les relations entre chameaux et société: Entre marginalisation et idéalisation. Ethnozootechnie 77: 43-50.

Faye, Bernard, Mohamed Jaouad, K. Bhrawi, Abdelhakim Senoussi, and Mohammed Bengoumi. 2014. Elevage camelin en Afrique du Nord: État des lieux et perspectives. Revue d'élevage et de médecine vétérinaire des pays tropicaux 67 (4): 213-221.

Harek, D. 2017. Contribution à l'étude de la diversité génétique des populations camelines (genre camelus) dans la région du Hoggar (Sud Algérien). In: Thèse de Magister en sciences agronomiques, option Sciences animales. Institut National d'Agronomie (INA) d'El Harrach. 114P.

Harek, D., and R. Bouhadad. 2008. La Diversité Des Élevages Camelins Dans La Région Du Hoggar (Wilaya De Tamanrasset). Colloque international : 'développement durable des productions animales : enjeux, évaluation et perspectives', Institut National d'agronomie (INA) Alger, Algérie.

Harek, Derradji, Hacene Ikhlef, Rachid Bouhadad, Hocine Sahel, Youcef Cherifi, Noreddine Djellout, M'hamed El Mokhefi, Semir Bechir Suheil Gaouar, and Fodil Arbouche. 2017. Genetic diversity status of camel's resources (Camelus dromedarius. Linnaeus, 1758) in Algeria. Genetics and Biodiversity Journal (GABJ) 1 (1): 43-65

Kadim, Isam T., and Osman Mahgoub. 2013. Camel Carcass Quality. Camel Meat and Meat Products, 98-112. Wallingford: CAB International.

Kamili, Asma, Bernard Faye, Nour Saïd Tligui, and Mohammed Bengoumi. 2020. Typologie des systemes d'elevage camelins du sud du Maroc. Revue d'élevage et de médecine vétérinaire des pays tropicaux 73 (2): 71-80.

Kouadja, S.G., A. Bakayoko, A.K. N'guessan, and C.N. Kouassi. 2018. Modes d'alimentation des ruminants en élevages urbains et périurbains de Bouaké (Côte d'Ivoire). Fourrages 233: 55-59.

Lasnami, K. 1986. Le Dromadaire En Algérie Perspective D'avenir. Thèse de magister en sciences agronomiques; option production animale. Institut National d'Agronomie (INA) El Harrach.

Lesnoff, M., R. Lancelot, and C.H. Moulin. 2007. Calcul des taux démographiques dans les cheptels domestiques tropicaux: approcheen temps discret, 74. Versailles: Editions Quae.

Longo-Hammouda, F.H., K. Toumi, A. Mouats, and N. Benlamnaouar. 2011. Contribution À La Connaissance De La Population Cameline Femelle «Tergui» Dans La Wilaya De Tamanrasset. Algerian Journal of Arid Environment 1 (1): 7.

Madani, T., B. Hubert, B. Vissac, and F. Casabianca. 2002. Analyse de l'activité d'élevage bovin et transformation des systèmes deproduction en situation sylvopastorale algérienne. Revue d'Elevage et de Médecine vétérinaire des Pays tropicaux 55 (3): 197-209. https://doi.org/10.19182/remvt.9824.
Ministère de l'Agriculture et du Développement Rural (MADR). 2015 Statistiques Agricoles. Ministère De L'agriculture Et Du Développement Rural. Directorate of Agricultural Statistics and Information System.

Ministère de l'Agriculture et du Développement Rural (MADR). 2018 Statistiques Agricoles. Ministère De L'agriculture Et Du Développement Rural. Directorate of Agricultural Statistics and Information System..

Michel, Jean-François, Mohammed Bengoumi, Pascal Bonnet, Kamel Hidane, K. Zro, and Bernard Faye. 1997. Typologie Des Systèmes De Production Camelins Dans La Province De Laâyoune, Maroc. Revue d'élevage et de médecine vétérinaire des pays tropicaux 50 (4): 313-323.

Moaeenuddin, M., M. Abdullah, K. Javed, and N. Ahmad. 2004. Feeding behavior of camel under stall feeding. The Journal of Animal Plant Science 14 (3-4): 7476.

Moskal, S. 1983. Essai D'évaluation du Bilan fourrager en Algérie Du Nord.I. Bilan énergétique. These d'ingeniorat en Agronomie. Institut National d'agronomie (INA). El-Harrach, 1-49.

Oulad Belkhir A, Chehma A and Faye B 2013 Phenotypic variability of two principal Algerian camel's populations (Targui and Sahraoui). Emirates Journal of Food and Agriculture, 25 (3): 231-237. https://doi.org/10.9755/ejfa.v2 5i3.15457. http://www.ejfa.info/.

Ouled Laid, A. 2008. Conduite De L'élevage Camelin (Région De Ghardaïa), Les Paramètres De Production Et De Reproduction, 112. Ouargla: Mémoire de fin d'étude, Université de Kasdi Merbah.

Pagès, J. 2002. Analyse Factorielle Multiple Appliquée Aux Variables Qualitatives Et Aux Données Mixtes. Revue de statistique appliquée 50 (4): 5-37.

Philippeau, G. 1986. Comment interpréter les résultats d'une analyse en composantes principales?: Collection STAT-ITCF. Institut Technique des Céréales et des Fourrages (ITCF).. https://infodoc.agroparistech.fr/index.php?lvl=notice display\&id=80080.

Salmi, C., M. Jaouad, B. Faye, and F. Haouat. 2018. Typologie Des Éleveurs Camelin Au Sud-Est Tunisien En Vue De Leurs Performances Économiques. Revue des Régions Arides 1 (44): 209-214.

Sawadogo, G.J., L.J. Pangui, M. Assane, and J.A. Akakpo. 1998. Etude De L'impact Socio-Économique Du Dromadaire Au Mali, En Mauritanie, Au Niger Et Au Tchad, Document $n^{\circ} 1$ : Enquêtes de terrain. Dakar: Ecole Inter-Etats des Sciences et Médecines Vétérinaires (EISMV).

StatSoft. 2008. Statistica, data analysis software system, version 8. Tulsa: TIBCO Software.

Tichit, M., S. Ingrand, C.H. Moulin, S. Cournut, J. Lasseur, and B. Dedieu. 2004. Analyser la diversité des trajectoires productives des femelles reproductrices: Intérêts pour modéliser le fonctionnementdu troupeau en élevage allaitant. INRA Productions Animales 17 (2): 123-132. https://doi.org/10.20870/ productions-animales.2004.17.2.3560.

Wernery, U. 2006. Camel milk, the white gold of the desert. Journal of Camel Practice and Research 13 (1): 15-26.

\section{Publisher's Note}

Springer Nature remains neutral with regard to jurisdictional claims in published maps and institutional affiliations.

\section{Submit your manuscript to a SpringerOpen ${ }^{\circ}$ journal and benefit from:}

- Convenient online submission

- Rigorous peer review

- Open access: articles freely available online

- High visibility within the field

- Retaining the copyright to your article

Submit your next manuscript at $>$ springeropen.com 